\title{
Determination of Thiocyanate by Kinetic Spectrophotometric Flow Injection Analysis
}

\author{
Mohsen Keyvanfard, ${ }^{1}$ Khadijeh Alizad, ${ }^{1}$ and Parinaz Elahian ${ }^{2}$ \\ ${ }^{1}$ Department of Chemistry, Majlesi Branch, Islamic Azad University, Isfahan, Iran \\ ${ }^{2}$ Department of Chemistry, Shahreza Branch, Islamic Azad University, Isfahan, Iran \\ Correspondence should be addressed to Mohsen Keyvanfard; keyvan45638@yahoo.com
}

Received 16 December 2011; Revised 26 May 2012; Accepted 9 June 2012

Academic Editor: Bartolo Gabriele

Copyright (c) 2013 Mohsen Keyvanfard et al. This is an open access article distributed under the Creative Commons Attribution License, which permits unrestricted use, distribution, and reproduction in any medium, provided the original work is properly cited.

A simple and rapid flow injection spectrophotometric method has been developed for the determination of amount of thiocyanate in wastewaters and well water samples. It is based on the reaction of thiocyanate in hydrochloric acid with janus green and bromate. Reaction was monitored spectrophotometrically by measuring janus green absorbance at $\lambda_{\max }=554 \mathrm{~nm}$. The calibration graph was linear over the range $0.02-1.0 \mu \mathrm{g} \mathrm{mL}^{-1}$ and the detection limit was $0.016 \mu \mathrm{g} \mathrm{mL}^{-1}(s / n=3)$. The throughput was 25 samples per hour.

\section{Introduction}

$\mathrm{SCN}^{-}$is a metabolite of cyanide detoxification with similar toxicity that has received attention from researchers in different fields such as medicine, food chemistry, and environmental sciences [1]. Thiocyanate usually exists in industrial waste waters, pesticides and organism metabolites. It is also present in low concentrations in human serum, saliva, and urine [2].

Different methods to determine thiocyanate in wastewaters, synthetic samples, biological samples, and food have been reported in the literature including spectrophotometric [3-6], fluorometric [7, 8], chromatographic [9-11], and electroanalytic approaches [12]. Some of these methods have a short linear range time consuming and expensive. Flowinjection analysis (FI) is characterised by its simplicity and speed, the inexpensive equipment needed and the accuracy of its results. It is an important alternative to other analytical methods, with clear advantages in terms of the short time required for each assay. In the bibliography, some FI methods [13-15] have been proposed for the determination of $\mathrm{SCN}^{-}$ in real samples.

In this paper an FI method, using spectrophotometric detection at $554 \mathrm{~nm}$, is described for the determination of thiocyanate. The method is based on inhibitory effect of thiocyanate on the oxidation of janus green by bromate in acidic medium. The proposed method has been successfully applied to the determination of thiocyanate in wastewaters and well water samples.

\section{Experimental}

2.1. Reagents. Analytical-reagent grade and doubly distilled water were used. A $2 \times 10^{-3} \mathrm{M}$ janus green solution was directly prepared by dissolving $0.1022 \mathrm{~g}$ of janus green (Merck, $\mathrm{M}=511.06 \mathrm{~g} / \mathrm{mol}$ ) in distilled water and diluting it with distilled water in a $100 \mathrm{~mL}$ volumetric flask. A $1 \times 10^{3} \mu \mathrm{g} / \mathrm{mL}$ stock standard solution of thiocyanate was prepared by dissolving $0.1673 \mathrm{~g}$ of potassium thiocyanate (Merck, $\mathrm{M}=97.181 \mathrm{~g} / \mathrm{mol}$ ) in distilled water and diluting it to $100 \mathrm{~mL}$. Working solutions were prepared by appropriately diluting the stock standard solution. A $100 \mathrm{~mL} 0.5 \mathrm{M}$ potassium bromate solution was prepared by dissolving $8.35 \mathrm{~g}$ of $\mathrm{KBrO}_{3}$ (Merck, $\mathrm{M}=167 \mathrm{~g} / \mathrm{mol}$ ) in distilled water and diluting it to mark in a $100 \mathrm{~mL}$ volumetric flask. Hydrochloric acid solution $(2.0 \mathrm{M})$ was prepared by diluting a known volume of its concentrated solution (Merck). 
2.2. Flow Injection System. Figure 1 shows the schematic diagram of the flow system. The 8-channel peristaltic pump (Ismatec, MCP process, IP 65) was fitted for pumping solutions. Silicon rubber tube with $0.8 \mathrm{~mm}$ i.d. was used for delivery of the solutions. A mixed solution of janus green, bromated, and hydrochloric acid as a carrier stream was delivered through silicon rubber tubing (at $40^{\circ} \mathrm{C}$ ). The thermostatic water bath (Gallen Kamp Griffin, BGL 240 V) was used at a given temperature of $40 \pm 0.1^{\circ} \mathrm{C}$. The standard solution of thiocyanate was injected into a carrier stream with a sample injector (Rhedyne, model 9125). An UV-visible spectrophotometer (2501 CECIL) equipped with a flowthrough cell with $10 \mathrm{~mm}$ path length connected a recorder was used for monitoring the variation in the absorbance spectrum.

2.3. Recommended FI Procedure. The flow-injection system is shown in Figure 1. Aliquots $(200 \mu \mathrm{L})$ of $\mathrm{SCN}^{-}$solutions prepared at different concentrations, $0.02-1.0 \mu \mathrm{g} \mathrm{mL}^{-1}$, were injected into a carrier stream containing of $0.5 \mathrm{M}$ hydrochloric acid reagent stream, which was then merged with $0.4 \mathrm{M}$ bromate stream and $1.5 \times 10^{-5} \mathrm{M}$ janus green stream; flow rate, $18 \mathrm{~mL} \mathrm{~h}^{-1}$; reaction coil, $50 \mathrm{~cm}$; detection wavelength, $554 \mathrm{~nm}$. Calibration graph was prepared by plotting the absorbance of the peak maximum versus $\mathrm{SCN}^{-}$concentration.

\section{Results and Discussion}

Janus green (Figure 2) undergoes an oxidation reaction with bromate in acidic medium at very fast rate. We found that ultratrace amounts of $\mathrm{SCN}^{-}$have an inhibitory effect on this reaction.

Mechanism of Reaction. Bromate is reduced by the chloride ion in acidic media:

$$
2 \mathrm{BrO}_{3}{ }^{-}+10 \mathrm{Cl}^{-}+12 \mathrm{H}^{+} \longleftrightarrow \mathrm{Br}_{2}+5 \mathrm{Cl}_{2}+6 \mathrm{H}_{2} \mathrm{O}
$$

Janus green reacts with the products of the reaction and is decolorized:

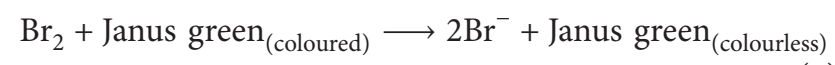

In presence of thiocyanate, we have following reaction in acidic medium [16]:

$$
4 \mathrm{Br}_{2}+\mathrm{SCN}^{-}+4 \mathrm{H}_{2} \mathrm{O} \longrightarrow \mathrm{SO}_{4}{ }^{2-}+\mathrm{BrCN}+7 \mathrm{Br}^{-}+8 \mathrm{H}^{+}
$$

Indeed, in presence of thiocyanate, reaction rate of 2 is decreased and thiocyanate has a inhibitory effect in this reaction and this reaction rate is sharply decreased by addition of trace amounts of thiocyanate.

This reaction is followed spectrophotometrically by controlling absorbance change of the dye at $554 \mathrm{~nm}$ by a flow injection method. To have best change absorbance between sample and blank, the effect of reagent concentrations and manifold variables on the analytical signal was studied. As a result, for determination of $0.4 \mu \mathrm{g} \mathrm{mL}^{-1}$, thiocyanate analytical signal was obtained 14.25 .

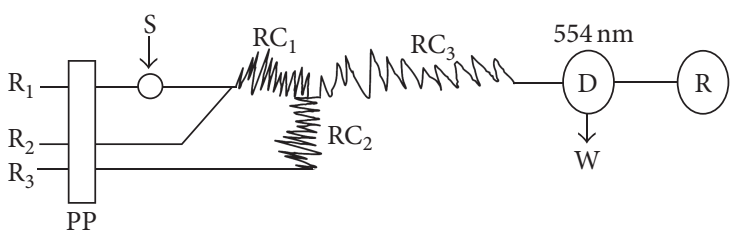

FIgure 1: Proposed FI manifolds. $\mathrm{R}_{1}$ : hydrochloric acid; $\mathrm{R}_{2}$ : bromate; $\mathrm{R}_{3}$ : janus green; PP: peristaltic pump; RC: reaction coil; $\mathrm{D}$ : detector; R: recorder; W: waste.<smiles>CCN(CC)c1ccc2nc3ccc(/N=N/c4ccc(N(C)C)cc4)cc3[n+](-c3ccccc3)c2c1</smiles>

FIGURE 2: Structure of janus green.

3.1. Effect of Chemical Variables. The influence of bromate concentration, janus green concentration and hydrochloric acid concentration, temperature, and ionic strength on the analytical signal was studied to find the optimum conditions. In figures drawn, peak height is change in absorbance (maximum peak height with the best baseline).

The influence of hydrochloric acid concentration on the analytical signal was studied in the presence of $0.1 \mu \mathrm{g} \mathrm{mL}^{-1} \mathrm{SCN}^{-}$and the optimum bromate concentration (Figure 3(a)). The results indicate that the best concentration for hydrochloric acid is $0.5 \mathrm{M}$. Therefore, the optimum hydrochloric acid concentration was selected to be $0.5 \mathrm{M}$.

The effect of janus green concentration on the analytical signal was studied at $0.1 \mu \mathrm{g} \mathrm{mL}^{-1} \mathrm{SCN}^{-}$and the optimum bromate concentration. The results in Figure 3(b) show that by increasing janus green concentration up to $2.0 \times$ $10^{-5} \mathrm{M}$, the analytical signal increases, but because of high concentration of janus green in channels and possibility of color stick to the wall channel, janus green concentration of $1.5 \times 10^{-5} \mathrm{M}$ was selected for next study.

Experiment was done at different bromate concentration. Figure 3(c) shows the maximum peak height with the best baseline is at $0.4 \mathrm{M}$. While higher bromate concentration decrease the signal. Therefore, a bromate concentration of $0.4 \mathrm{M}$ was selected as the optimum bromate concentration.

Figure 4 show the influence of temperature on the maximum signal $(\Delta \mathrm{A})$ was studied for the range of $15-50^{\circ} \mathrm{C}$, under above conditions, as previously described. The results show that by increasing temperature up to $40^{\circ} \mathrm{C}$, analytical signal increases. So temperature was fixed at $40^{\circ} \mathrm{C}$.

3.2. Effect of Manifold Variables. Influence of variables such as reaction coils, injected volume, and flow rate on the analytical signal was studied. The peak height depends on the residence time of the sample in the system that is affected by flow rate and reaction coil lengths. 


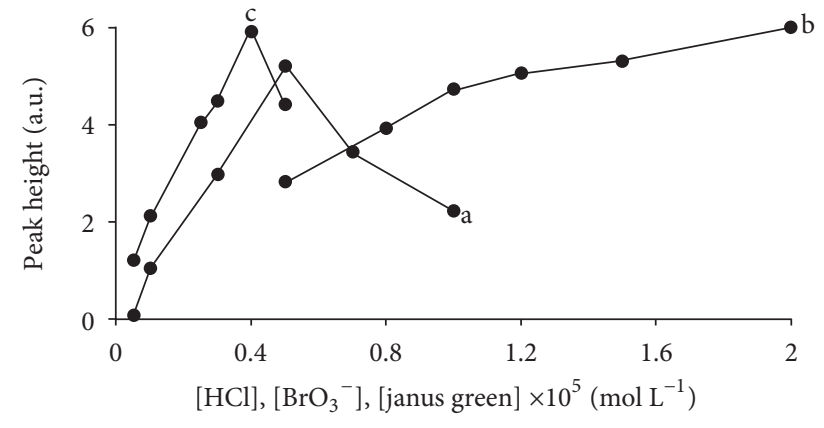

FIGURE 3: Effect of (a) hydrochloric acid (b) janus green, and (c) bromate concentrations on the mean of peak height $(n=5)$ of $0.1 \mu \mathrm{g} \mathrm{mL}^{-1}$ thiocyanate standard solution.

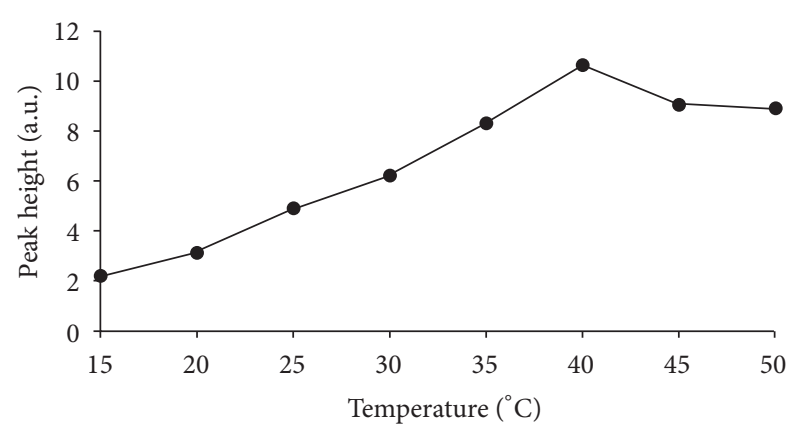

FIgURE 4: Effect of temperature on the sensitivity. Conditions: $0.5 \mathrm{M}$ hydrochloric acid, $2 \times 10^{-5} \mathrm{M}$ janus green, $0.4 \mathrm{M}$ bromate, $0.1 \mu \mathrm{g} \mathrm{mL}^{-1}$ thiocyanate, sample loop volume of $200 \mu \mathrm{L}$, flow rate of $18 \mathrm{~mL} / \mathrm{h}$ for each channel, three reaction coil lengths from $\mathrm{RC}_{1}$ to $\mathrm{RC}_{3}, 40 \mathrm{~cm}, 40 \mathrm{~cm}$, and $150 \mathrm{~cm}$, respectively.

TABLE 1: Effect of common excipients and other possible interferents on the determination of $0.1 \mu \mathrm{g} \mathrm{mL}^{-1}$ of thiocyanate.

\begin{tabular}{lc}
\hline Species assayed & Tolerated ratio \\
$W_{\text {Species }} / W_{\text {thiocyanate }}$ \\
\hline $\mathrm{Ca}^{2+}, \mathrm{Na}^{+}, \mathrm{NO}_{3}{ }^{-}, \mathrm{CO}^{2+}, \mathrm{Al}^{3+}, \mathrm{K}^{+}, \mathrm{CL}^{-}$ & 1000 \\
$\mathrm{Mn}^{2+}, \mathrm{Ba}^{2+}$ & 500 \\
$\mathrm{Cu}^{2+}, \mathrm{Mg}^{2+}$ & 300 \\
$\mathrm{Hg}^{2+}, \mathrm{Fe}^{2+}, \mathrm{Ni}^{2+}$ & 100 \\
$\mathrm{I}^{-}, \mathrm{Ag}^{+}$ & 20 \\
$\mathrm{~S}_{2} \mathrm{O}_{3}{ }^{2-}$ & 5 \\
\hline
\end{tabular}

The results during the investigation of the effect of three reaction coil lengths show that by increasing the reaction coil length up to $\left(\mathrm{RC}_{1}\right) 30 \mathrm{~cm},\left(\mathrm{RC}_{2}\right) 40 \mathrm{~cm}$, and $\left(\mathrm{RC}_{3}\right) 150 \mathrm{~cm}$, the sensitivity increases. At shorter distances, there is not enough time for reagents to be mixed and above this reactor length, increased dispersion will decrease the peak height (Figure 5).

The influence of sample volume was tested under optimum conditions. The results show that the peak height rose by increasing the volume of sample loop volume, but the injection of a large amount of sample results in peak

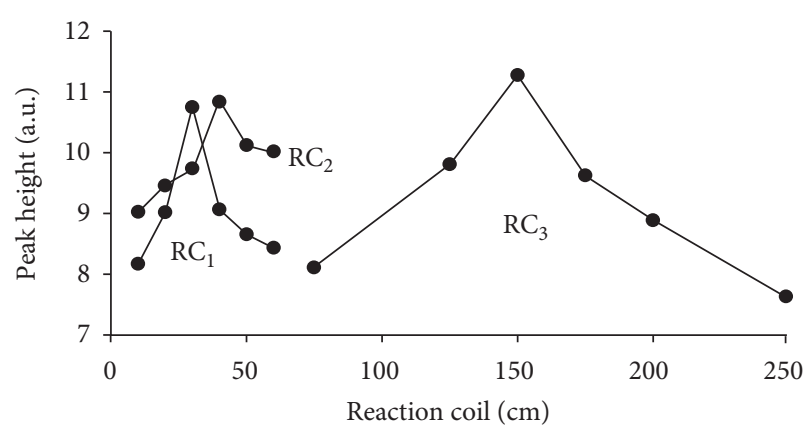

FIGURE 5: Effect of reaction coil lengths on the sensitivity. Conditions: $0.5 \mathrm{M}$ hydrochloric acid, $2 \times 10^{-5} \mathrm{M}$ janus green, $0.4 \mathrm{M}$ bromated, $0.1 \mu \mathrm{g} \mathrm{mL}^{-1}$ thiocyanate, temperature of $40^{\circ} \mathrm{C}$, sample loop volume of $200 \mu \mathrm{L}$, and flow rate of $18 \mathrm{~mL} / \mathrm{h}$ for each channel.

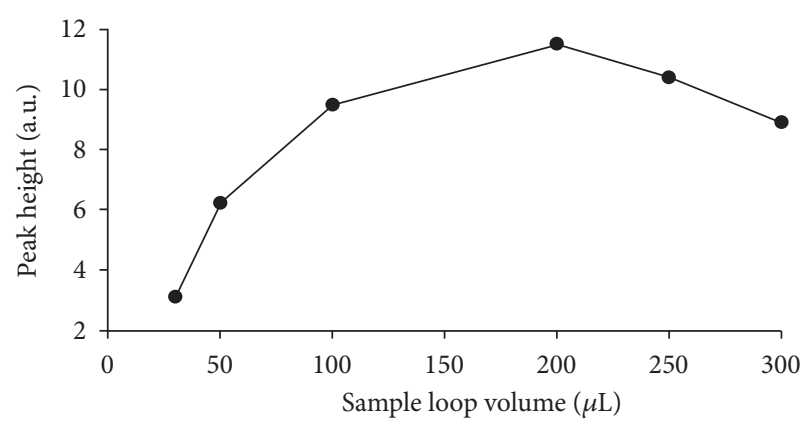

FIGURE 6: Effect of sample loop volume on the sensitivity. Conditions: $0.5 \mathrm{M}$ hydrochloric acid, $2 \times 10^{-5} \mathrm{M}$ janus green, $0.4 \mathrm{M}$ bromated, $0.1 \mu \mathrm{g} \mathrm{mL}^{-1}$ thiocyanate, temperature of $40^{\circ} \mathrm{C}$, flow rate of $18 \mathrm{~mL} / \mathrm{h}$ for each channel, three reaction coil lengths from $\mathrm{RC}_{1}$ to $\mathrm{RC}_{3}, 30 \mathrm{~cm}, 40 \mathrm{~cm}$, and $150 \mathrm{~cm}$, respectively.

TABle 2: Determination of thiocyanate in real samples.

\begin{tabular}{lcccc}
\hline Sample & $\begin{array}{c}\text { Added } \\
\left(\mu \mathrm{g} \mathrm{mL}^{-1}\right)\end{array}$ & $\begin{array}{c}\text { Expected } \\
\left(\mu \mathrm{g} \mathrm{mL}^{-1}\right)\end{array}$ & $\begin{array}{c}\text { Founded } \\
\left(\mu \mathrm{g} \mathrm{m}^{-1}\right)\end{array}$ & $\begin{array}{c}\text { Recovery } \\
\%\end{array}$ \\
\hline $\begin{array}{l}\text { Drinking water } \\
\text { (Majlesi) }\end{array}$ & 0 & 0 & - & - \\
& 0.12 & 0.12 & 0.114 & 95 \\
Wastewaters & 0.12 & 0.24 & 0.259 & 108 \\
(Majlesi) & 0.12 & 0.22 & 0.205 & - \\
& 0.12 & 0.34 & 0.354 & 104 \\
\hline Well water & 0 & 0 & - & - \\
(Majlesi) & 0.06 & 0.06 & 0.058 & 97 \\
& 0.12 & 0.18 & 0.182 & 101 \\
\hline
\end{tabular}

broadening and tailing. Thus, a sample volume of $200 \mu \mathrm{L}$ was selected (Figure 6).

The effect of flow rate was tested under optimum chemical conditions. The results show that the best pump flow rate (the maximum peak height and minimum dispersion) will be obtained in $18 \mathrm{~mL} \mathrm{~h}^{-1}$ for each channel. At lower flow rates the dispersion will be high whereas at greater flow rates the reaction may be incomplete (Figure 7). 
TABLE 3: A comparison of detection limit and linear dynamic range of several methods with the proposed method.

\begin{tabular}{|c|c|c|c|}
\hline Method & $\begin{array}{c}3 \sigma \text { detection limit } \\
\left(\mu \mathrm{g} \mathrm{mL}^{-1}\right)\end{array}$ & $\begin{array}{l}\text { Linear dynamic range } \\
\left(\mu \mathrm{g} \mathrm{mL}^{-1}\right)\end{array}$ & Reference \\
\hline Spectrophotometric & 4.8 & 48.5 to 971.81 & [3] \\
\hline Kinetic spectrophotometric & 0.005 & 0.02 to 0.8 & {$[4]$} \\
\hline Kinetic spectrophotometric & - & 0.6 to 0.7 & {$[5]$} \\
\hline Ion chromatography & - & 1 to 30 & {$[10]$} \\
\hline Chromatography & 0.05 & - & {$[11]$} \\
\hline Electrochemical & 0.004 & 0.05 to 38.8 & {$[12]$} \\
\hline Proposed method & 0.016 & 0.02 to 1.0 & - \\
\hline
\end{tabular}

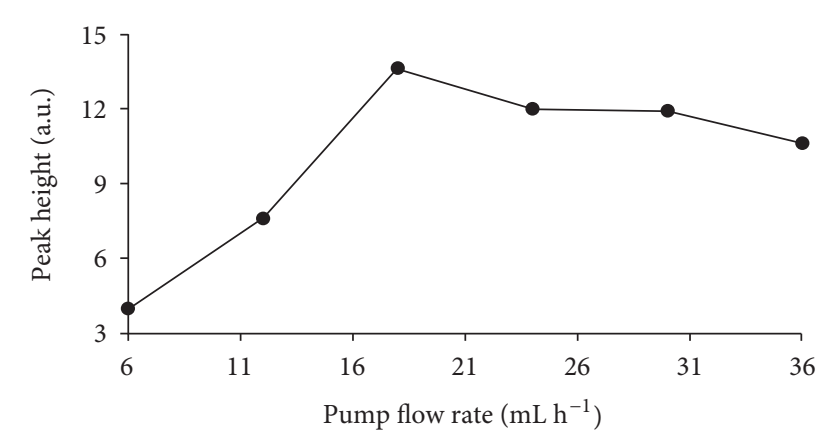

Figure 7: Effect of flow rate for each channel on the sensitivity. Conditions: $0.5 \mathrm{M}$ hydrochloric acid, $2 \times 10^{-5} \mathrm{M}$ janus green, $0.4 \mathrm{M}$ bromated, $0.1 \mu \mathrm{g} \mathrm{mL}^{-1}$ thiocyanate, temperature of $40^{\circ} \mathrm{C}$, sample loop volume of $200 \mu \mathrm{L}$, three reaction coil lengths from $\mathrm{RC}_{1}$ to $\mathrm{RC}_{3}$, $30 \mathrm{~cm}, 40 \mathrm{~cm}$, and $150 \mathrm{~cm}$, respectively.

3.3. Analytical Characteristics of the FI Spectrophotometric Method. The calibration graph was obtained by the procedure described in Section 2, whereby a series of standard solutions was analysed in triplicate to test the linearity. The calibration graph obtained was linear in the range $0.02-1.0 \mu \mathrm{g} \mathrm{mL}^{-1}$. The equation of the calibration graph is $\left(\Delta \mathrm{A}=1.8469 \mathrm{C}_{\text {thiocyanate }}+13.5212\right.$, where $\Delta \mathrm{A}$ is change in absorbance (maximum peak height with the best baseline) for the sample and $\mathrm{C}_{\text {thiocyanate }}$ is thiocyanate concentration expressed in $\mu \mathrm{g} \mathrm{mL}^{-1}$, with a correlation coefficient $r=0.9954$. The limit of detection calculated according to the recommendations of IUPAC [17], was $0.016 \mu \mathrm{g} \mathrm{mL}^{-1}$ $(n=10)$. The between-run precision of the method was tested by analysing five replicate samples of $0.3,0.5$, and $0.8 \mu \mathrm{g} \mathrm{mL}^{-1}$ of thiocyanate. The coefficients of variation were $\pm 0.68 \%$, $\pm 0.56 \%$, and $\pm 0.45 \%$.

3.4. Selectivity. The interference of possible coexisting substances was studied. The sample containing $0.1 \mu \mathrm{g} \mathrm{mL}^{-1}$ of thiocyanate, and various concentrations of the foreign substance was injected into the flow system. The tolerance limit was taken as the concentration causing an error of not more than $\pm 3 \%$ in the determination of thiocyanate. The results obtained are shown in Table 1 . As can be seen, the proposed method is very selective.
3.5. Analytical Application. The proposed method has been successfully applied to determine thiocyanate in the real and synthetic water and wastewater samples. The results in Table 2 represent that good recoveries in all samples were obtained.

\section{Conclusion}

A simple, rapid, and selective flow injection inhibition procedure is developed for the determination of thiocyanate with spectrophotometric detection. This method can be used for the determination of $\mu \mathrm{g} \mathrm{mL}^{-1}$ amounts of thiocyanate with a sample rate of $25 \pm 5$ samples/h. The main advantages of the method are its simplicity and its large dynamic range which make it possible to determine thiocyanate in the real samples with satisfactory results. The flow injection system developed for the determining thiocyanate is inexpensive; it employs available reagents, allows rapid determination at low operating cost, and provides simplicity, adequate selectivity, and a low limit of detection compared to some of referenced methods. A comparison of detection limit and linear dynamic range of several methods with the proposed method is shown in Table 3.

\section{Acknowledgment}

The authors express their gratitude to the Center of Excellency in Science of Islamic Azad University, Majlesi and Shahreza, for the support of this work.

\section{References}

[1] A. F. Lavorante, M. A. Feres, and B. F. Reis, "Multicommutation in flow analysis: a versatile tool for the development of the automatic analytical procedure focused on the reduction of reagent consumption," Spectroscopy Letters, vol. 39, no. 6, pp. 631-650, 2006.

[2] G. F. Wang, M. G. Li, Y. C. Gao, and B. Fang, "Amperometric sensor used for determination of thiocyanate with a silver nanoparticles modified electrode," Sensors, vol. 4, no. 9, pp. 147-155, 2004.

[3] J. J. Silva Júnior, M. A. Farias, V. L. Silva et al., "Spectrophotometric determination of thiocyanate in human saliva employing micropumping multicommutation flow system," Spectroscopy Letters, vol. 43, no. 3, pp. 213-219, 2010.

[4] M. A. Chamjangali, G. Bagherian, and N. Salek-Gilani, "Determination of trace amounts of thiocyanate by a new kinetic 
procedure based on an induction period," Spectrochimica Acta-Part A, vol. 67, no. 5, pp. 1252-1256, 2007.

[5] A. A. Ensafi, T. Khayamian, and R. Tabaraki, "Simultaneous kinetic determination of thiocyanate and sulfide using eigenvalue ranking and correlation ranking in principal componentwavelet neural network," Talanta, vol. 71, no. 5, pp. 2021-2028, 2007.

[6] H. Karimi and M. Ghaedi, "Simultaneous determination of thiocyanate and salycilate by a combined UVspectrophotometric detection principal component artificial neural network," Annali di Chimica, vol. 96, no. 11-12, pp. 657-667, 2006.

[7] J. Kong, J. Fan, and S. Feng, "Kinetic fluorimetric determination of trace thiocyanate in saliva," Journal of Instrumental Analysis, vol. 25, no. 1, p. 109, 2006.

[8] B. Gong and G. Gong, "Fluorimetric method for the determination of thiocyanate with $2^{\prime}, 7^{\prime}$-dichlorofluorescein and iodine1," Analytica Chimica Acta, vol. 394, no. 2-3, pp. 171-175, 1999.

[9] R. A. Niemann and D. L. Anderson, "Determination of iodide and thiocyanate in powdered milk and infant formula by online enrichment ion chromatography with photodiode array detection," Journal of Chromatography A, vol. 1200, no. 2, pp. 193-197, 2008.

[10] E. Saussereau, J.-P. Goullé, and C. Lacroix, "Determination of thiocyanate in plasma by ion chromatography and ultraviolet detection," Journal of Analytical Toxicology, vol. 31, no. 7, pp. 383-387, 2007.

[11] J. Xu, Y. Wang, Y. Xian et al., "Simultaneous determination of oxalate, thiosulfate, and thiocyanate in urine by ionexclusion chromatography with electrochemical detection," Chromatographia, vol. 56, no. 7-8, pp. 449-453, 2002.

[12] M. Li, G. Wang, Y. Gao, and B. Fang, "Determination of trace thiocyanate with glassy graphite electrode modified with nanosize silver," Physical Testing and Chemical Analysis, vol. 41, no. 5, p. 305, 2005.

[13] H. Sulistyarti, S. D. Kolev, and S. Lim, Indonesian Journal of Chemistry, vol. 10, p. 167, 2010.

[14] A. Tanaka, M. Miyazaki, and T. Deguchi, "New simultaneous catalytic determination of thiocyanate and iodide by flow injection analysis," Analytical Letters, vol. 18, no. 6, pp. 695-705, 1985.

[15] D. V. Brown, N. A. Chaniotakis, I. H. Lee et al., "Mn(III)porphyrin-based thiocyanate-selective membrane electrodes: characterization and application in flow injection determination of thiocyanate in saliva ", Electroanal, vol. 1, no. 6, pp. 477-484, 1989.

[16] I. R. Epstein, K. Kustin, and R. H. Simoyi, "Kinetics and mechanism of the reaction of bromine with thiocyanate," Journal of Physical Chemistry, vol. 96, no. 15, pp. 6326-6331, 1992.

[17] IUPAC Nomenclature, "Nomenclature, symbols, units and their usage in spectrochemical analysis-II. Data interpretation," Pure and Applied Chemistry, vol. 45, no. 2, pp. 99-103, 1976. 

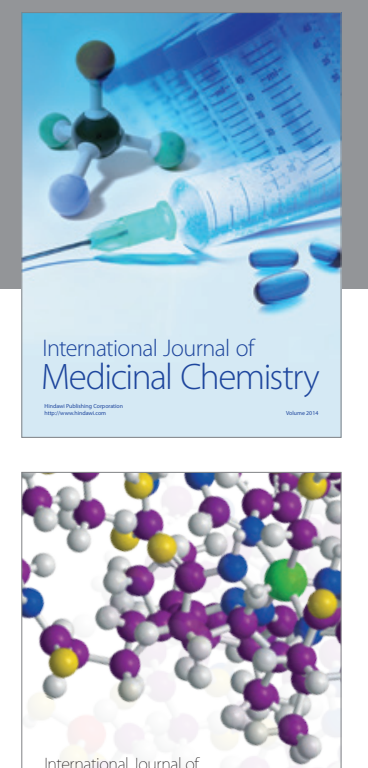

\section{Carbohydrate} Chemistry

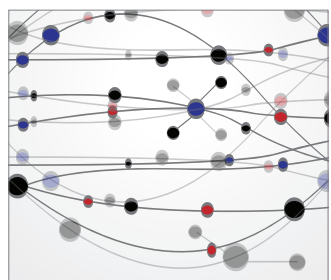

The Scientific World Journal
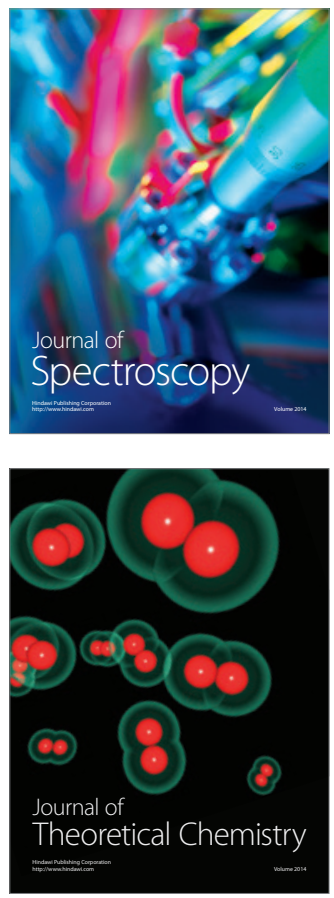
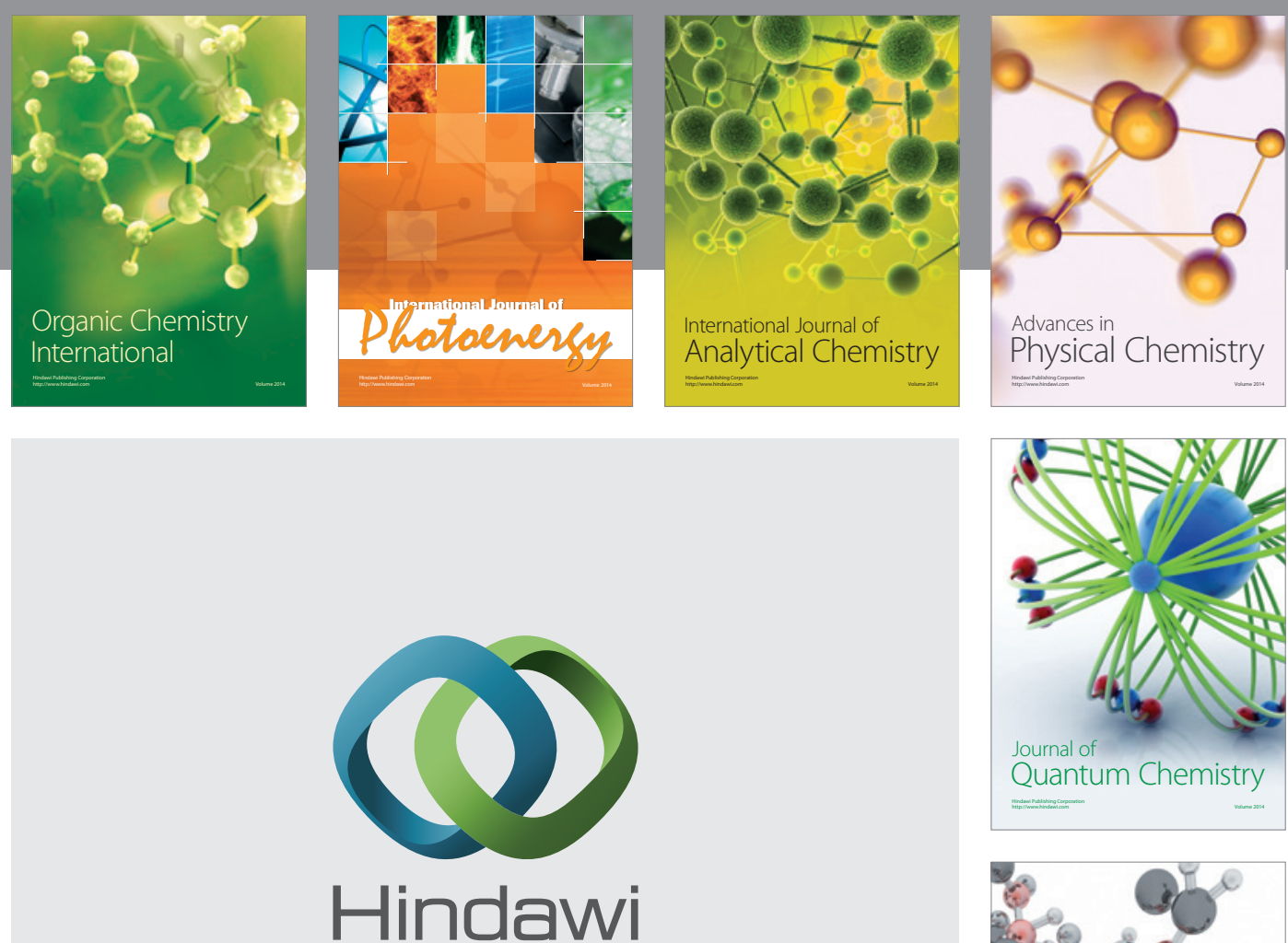

Submit your manuscripts at

http://www.hindawi.com

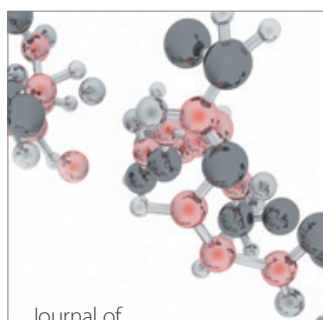

Analytical Methods

in Chemistry

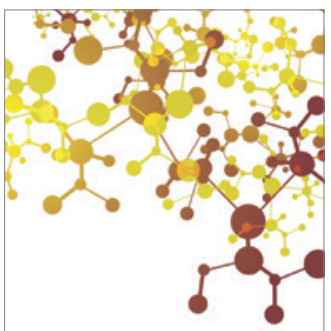

Journal of

Applied Chemistry

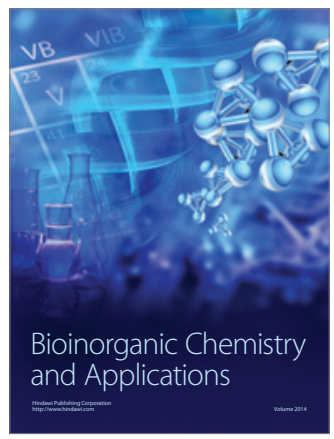

Inorganic Chemistry
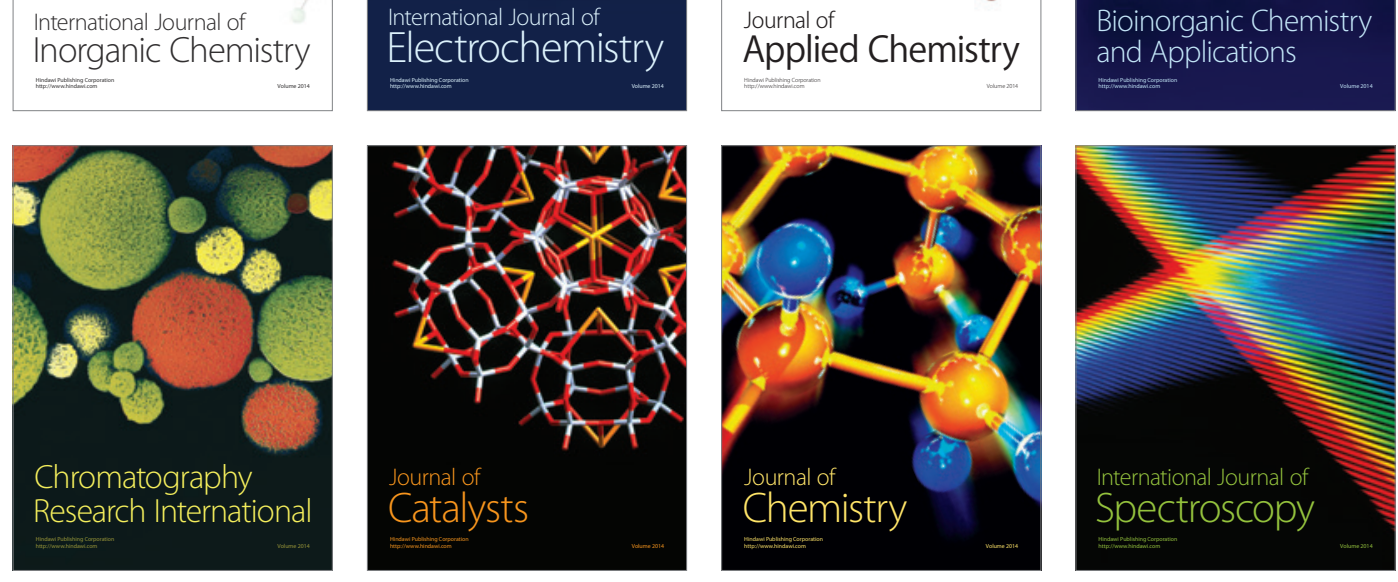